\title{
Foreign Policy of Pakistan: Challenges and Opportunities
}

\author{
Sajeela Yousaf and Dr. Shaista Tabassum \\ SZABIST \\ Karachi, Pakistan
}

\begin{abstract}
:
The Purpose of this study is not to concentrate on Pakistan's relations with the rest of world but to focus on the challenges faced by Pakistan's foreign policy and opportunities available to it in this changed international scenario after $9 / 11$ and US attack on Iraq. In the end are mentioned important steps that Pakistan needs to undertake in order to exist as an independent state in order to make independent internal as well as external policies so that it can be free from the influence of big powers specifically from the influence of the sole super power.
\end{abstract}

\section{INTRODUCTION}

Towards the end of twentieth century, when Communism and Soviet Union were defeated in Afghanistan mainly with the help of Mujahideen, financed and supported by the other super power USA, a unipolar world began to emerge. Soviet Union disintegrated; Communism was seen to be a failed social, political and economic ideology. A victory for west sponsored capitalist ideology based on maximization of profit, free trade and free market was quite apparent. There appeared to be a move from bipolar world to a multipolar system (with the emergence of EU, ASEAN and due to the presence of countries like China, France, Germany and Russia). What actually happened were the tragic events of 9/11. These attacks were declared terrorist attacks by US administration and it started hunt for invisible enemy. President Bush vowed to find those who were responsible and bring them to justice. The 'new' enemy was terrorism that became a justification for everything. US tried to unite whole world to fight this menace. This war was initially declared a crusade by President Bush. The links were traced to Al-Qaeda organization an Islamic militant Organization led by Osama bin Laden without investigation. Afghanistan was attacked to punish Taliban regime for harboring terrorists when they refused to hand over Osama to US Administration without any evidence. UNO provided a legal cover for this action. NATO countries also supported Washington in order to save themselves from fundamentalist Muslims who according to Western governments were jealous of the prosperity of Western World. Pakistan the most sanctioned country in the world during 1990's once again became a frontline state in US war against terrorism due to its geo-strategic importance.

Second phase of US war against terrorism was its decision to attack Iraq in order to punish despotic ruler Saddam Hussein for making weapons of mass destruction. Washington took responsibility to liberate Iraqi people from the tyranny of Saddam who was accused of maltreating his people. After the failure of Arms inspectors appointed by UNO US decided to attack Iraq. This time situation was little bit different as except Britain, Australia and Spain rest of the world including Pakistan opposed the use of military force against Iraq.

\section{DETERMINANTS OF PAKISTAN'S FOREIGN POLICY}

There is a great responsibility on the shoulders of those who are entrusted with the task of formulation of foreign policy and for its implementation. It is usually believed that in case of developing countries like ours foreign policy sometimes become important than internal policies. As far as Pakistan is concerned there are certain factors that play an important role in the determination of its foreign policy. Important concerns of Pakistan's foreign policy are:

\subsection{National Security}

The most important concern of Pakistan's foreign policy is national security in the presence of hostile India and politically instable Afghanistan.

\subsection{Islamic Ideology}

Another important determinant is Ideology. There is a great commitment to Islam among the people of this region. Pakistan's creation is unique in a sense that it was created on the basis of religious ideology. This ideological aspect influences the internal as well as foreign policy decisions of Pakistan.

\subsection{Geo-strategic Location of Pakistan}

Geo-strategic location of Pakistan has always played an important role in the formulation of its foreign policy as it 
shares borders with China, India, and Iran Afghanistan and very close to Central Asian Republics (former Soviet Union).

\subsection{Economic Factor}

Another motivation of Pakistan's foreign policy has been its economic interests. At the time of partition, Pakistan inherited a very weak economy. The economic interests of under-developed countries like Pakistan play an important role in the formulation of their foreign policy.

\section{CHALLENGES FACED BY PAKISTAN'S FOREIGN POLICY}

Important challenges faced by Pakistan in Changed world scenario after $9 / 11$ are mentioned below:

\subsection{Pakistan's Nuclear Program}

The most important challenge faced by Pakistan's foreign Policy is related to its nuclear capability especially when US has started a campaign against countries making weapons of mass destruction. Pakistan being the only Islamic country that has nuclear capability is facing number of problems. As a matter of fact USA from the very beginning was against Pakistan being an Islamic state becoming a nuclear power while it was not bothered by India's nuclear program. Recently numerous media reports, quoting unnamed US intelligence officials, have alleged that Pakistan exported nuclear technology to North Korea [1].

\subsection{Anti-terrorism Movement}

Pakistan from the very beginning even before 9/11 when it carried the distinction of the most sanctioned country in the world has supported US to fight this menace of terrorism. The government of Pakistan decided to hand over Amil Kansi and Ramzi yusuf to USA because of their alleged involvement in terrorist activities. After terrorist attacks of 9/11, Pakistan's government was under tremendous pressure to cooperate with US as it shared a long border with Afghanistan. When military government of Pakistan decided to cooperate with US to attack Afghanistan despite its betrayals in the past, people of Pakistan opposed it. India after $9 / 11$ has found the world, particularly the West more receptive to its calls for firm action against terrorism in Kashmir and Pakistan was accused of supporting terrorist activities in Kashmir and India. After US attack on Iraq, Delhi once again tried to use the United States-led pre-emptive war against Iraq as a pretext for an attack on Pakistan. So Pakistan is faced with a serious challenge on one hand by supporting Washington in its war against terrorism and on the other hand it is countering Indian accusations that Pakistan is involved in cross border terrorism in Kashmir.

\subsection{Economy of Pakistan}

There existed a strong sense of betrayal by the US among the people of Pakistan in general, and the Pakistani military and political establishment in particular. Pakistan was left all alone to deal with the legacies of Afghan war against Soviets. More than three million refugees and resulting economic fall out were two important consequences of Afghan war. Thus to support US after 9/11 events meant to increase problems for Pakistan's economy which was badly affected due to the sanctions imposed on Pakistan after Soviet withdrawal from Afghanistan. Later India massed its troops on Pakistan's border after terrorist attack on Indian parliament also created problems for Pakistan's economy.

\section{OPPORTUNITIES}

In this section of independent study focus is on number of opportunities available to Pakistan in post 9/11 period.

\subsection{Economic Benefits}

The 9/11 events contributed towards the improvement in economy, which was in worst conditions during 1990s due to sanctions imposed on Pakistan by USA, Europe and Japan, countries providing economic and military assistance to Pakistan. Sanctions were lifted by US as well as other countries. US decided to write off $\$ 1$ billion debt of Pakistan and total debt relief approved for Pakistan was of $\$ 12.5$ billion by donor countries [2].

\subsection{Pakistan's Geo-strategic Location}

Once again geo-strategic location of Pakistan has forced US to take dramatic turn in its policies towards this state. This time US is here to stay for a much longer period of time due to its economic interests in Central Asia and Caspian Basin. Then due to Gawadar port Pakistan can get economic benefits from China by helping it to develop its western provinces and US by providing it the shortest route to transport hydrocarbons from Central Asia to outside world. Pakistan can also provide port facilities to land locked countries of Central Asia and Afghanistan. Pakistan can get $\$ 600$ million to $\$ 800$ million by providing transit route for gas pipeline to India from Turkmenistan. 
It can play an important role in the reconstruction of Afghanistan and by developing infrastructure in Central Asian states.

\subsection{From Unipolar to Multipolarism; An Opportunity for Pakistan}

As Pakistan like the rest of world is not sure that how US will behave in pursuit of its unilateralist ambitions for world domination. World is definitely moving from unilateralism to multilateralism and from unipolar to multipolar system after US attack on Iraq. Pakistan in view of its past experiences with US as it has never been proved a trustworthy ally should consider the opportunity to gradually lower its dependence on Washington.

\subsection{Improvement of Economic Relations With EU}

Pakistan's relations have improved with European Union after 9/11. EU decided to take number of steps in order to contribute towards political and economic stability of Pakistan. It has approved a 71 million Euro grant for Pakistan to help in improving governance and accountability in educational sector and increased textile quota by $15 \%$ [3]. In post $9 / 11$ period Pakistan has an opportunity to improve trade relations with EU.

\subsection{Regional Cooperation}

After 9/11 changed world scenario has also has its impact on South Asian region. Pakistan has an opportunity to improve relations with Russia as it is no longer a super power but remains an important Eurasian power. In line with Russia's new pragmatic foreign policy approach, it is looking to diversify its regional cooperation. Pakistan has an opportunity to further strengthen its relations with China as with the highest economic growth rate at present China is going to be world's biggest economic power by the year 2025. In order to strengthen this region Pakistan has an opportunity to normalize and improve relations with India and to make SAARC more effective on the lines of other economic alliances like EU and ASEAN.

\subsection{Relations with Muslim Countries}

After 9/11 another development is revival of Muslim identity among the people of Islamic states. Pakistan being an Islamic country can play an important role in bringing Muslim countries together. It has an opportunity to develop people to people contacts and trade relations. Islamic countries can pool in their huge resources in developing infrastructure, education and health sectors, banks and media. Pakistan has also an opportunity to start barter trade with some of the countries in Middle East.

\section{CONCLUSION}

In the wake of developments that took place on world scenario after $9 / 11$ it is very important for those entrusted with the task of the formulation of Pakistan's foreign policy to review it. The founding fathers of Pakistan wanted to make it an economically stable tolerant state, free from legal and political discrimination that could serve as a role model for other Islamic states of the world. In Pakistan since partition Islam has been used by different sections of society with their vested interests to exploit masses, to gain political benefits and above all to rule country. In order to have an ideological state it is very important to have a state structure. It can only be achieved under the rule of democratic regime that can make a foreign policy based on national consensus. So the most important thing is to revive political process and to free foreign policy from the influence of military, intelligence agencies civil bureaucracy and feudal lords. It can help Pakistan to exist as an independent state free from the influence of other powers especially from the influence of the sole super power.

It is important to gradually lower dependence on US and to promote economic ties with other economic and military blocks. Pakistan's foreign policy objective should be to improve relations with Russia and to achieve peace with India. It can also help in strengthening this region of South Asia and can help in making SAARC an effective organization.

Pakistan's internal as well as foreign policies should be aimed at improving its economy as in order to have an independent policies it is very important for states to have self-reliant economy. Due to common Islamic ideology Pakistan needs to improve relations with Muslim world by increased people to people contacts. Pakistan should be able to make long-term policies in national interest by giving up ad hocism and reactionary policies. This ad hocism is due to the absence of independent planning and research division in Pakistan's foreign office and lack of involvement of scholars and academic experts in foreign policy planning. Making an advisory board including foreign relations experts from top universities in country can do this. There is a need to make a definite foreign policy keeping in view the recommendations from this advisory board. 


\section{REFERENCES}

[1] North Korea gave missile technology to Pakistan, DAWN, April 3, 2003.

[2] DAWN, April 8, 2003.

[3] http://europa.eu.int/comm./external_relations/ Pakistan/intro/ 